\title{
Revolutions and Preventive Democracy in the Age of Extremes
}

\author{
Jozef Lysý \\ Commenius University in Bratislava, SK
}

\begin{abstract}
LYSÝ, J.: Revolutions and Preventive Democracy in the Age of Extremes.

Philosophica Critica, vol. 2, 2016, no. 1, ISSN 1339-8970, pp. 23-32
\end{abstract}

\begin{abstract}
Revolutions are events commencing the modern era. The event is accompanied by a new order being established, which means a considerable innovation. In the twentieth century wars and revolutions prevailed. Globalization brings into this process a dynamics manifested in neverending changes that have also had an impact on transformation of democracy. The deepening incommensurability of social positions has currently created separate social worlds. In addition to the fact that uncertainty is growing in the society as an unintended consequence, politics under this pressure is controlled by a forced, preventive manner of its functioning. The question is whether people will be able to use power within the politics trumped up in this way. The purpose of elites then is to remove people from power. Even democracy, in the state it is today in its efforts to be a politics is manifested as a prevention to bar undesirable conditions, situations and circumstances for the capital. In this respect it has become an arrangement removing the relationships of protection brought about and established by the modern society. It expropriates the relationship it has created, thus being unable to face the consequences of its own policies. It has been a repressive force of financial capital that has been facilitating "preventive democracy".
\end{abstract}

Key words: Revolution - Transformation - Preventive democracy Globalization

It is the author's observation that the issue of change involves a change of the form of the societal structure, its transformation, in particular the transformation of capitalism. In this context, N. Fraser suggests distinguishing affirmative and transformative strategies within the term transformation. The strategies known from the past have been changing their appearance within the globalization pro- 
cess. Therefore, the strategy of societal change shall face new challenges. W. I. Robinson has concluded that due to the globalization effect the worldwide capitalism is set to face a systemic crisis. This has become visible in 2008. The system seems to be heading for a crisis akin to the times of unrest and insecurities experienced in world wars and crises of the first half of the twentieth century. However, at this time the author shall not examine the issue from the academic point of view; he would rather discuss its political repercussions. The crisis is certainly global, affecting civilization as a whole, and its impacts will depend on the competing social performers involved. To understand the workings of global capitalism it is necessary to comprehend the inner dynamism of capitalism. Globalization is manifested as the rise of trans-national capital, globally integrated production and financial systems. Trans-national capitalist class has increased its power. Trans-national accumulation (various neo-liberal policies, free trade agreements, privatization, deregulation, integration of revolutionary countries of the Soviet block and the third world into the system of global market and production, etc.) helped to enhance its position in the eighties and the nineties of the twentieth century. The contemporary reality thus offers a complex picture of the world transformation. Globalization is a complex process. Similarly to that, at the beginning of the World War I it found itself in contradiction with the interests of western countries in particular. The sources of economic growth had been located beyond the borders of the historical West, the artificial sources of growth provided by the banks were insufficient, the investing social groups of population became rentiers, and this did not help the development of countries, as it was in France a hundred years ago, by the way. The trends to de-globalization and regionalization of global economics appeared, new business structures of hansa type have been proposed. Unambiguous consensus cannot be found to answer these questions, objective factors as well as subjective deviations have been shaped in the context of global trends and their crystallisation is not balanced or steady. As a result, numerous analysts apply analogies with the past, often using the Chinese opinions. The statement of Chou En-Lai, that time has not yet come to understand the French revolution, is often quoted. The declaration is related to the need to understand the contemporary situation while noting that we do not know whether we will have enough time to understand objectively the relationships of causes and their consequences as for the situation today. Within globalization, we come across the phenomenon of overloading of the information space. Moreover, the contemporary political techniques have escalated the conflict of collective survival. 


\section{Revolutions in tradition}

The modern concept of revolution has been used since the times of Copernicus. In political sense, revolution is a sudden, abrupt change linked with a popular movement. We relate it to American, French or Russian revolutions. However, radical changes occurred in other eras and other cultures too. There is one single and real difference between revolution and transformation: that revolution is radical; Machiavelli's lions act hastily while Machiavelli's foxes hidden in the background are waiting for their prey (Keller 2014, 18). Marek Hrubec flags up an ambivalent nature of social and political processes, the problem of simplified grasping of the progress and people striving for their recognition in the society; all these factors may impact on development trends in the world. There is both a progress and a regress and in the era of stagnation, social movement can be positively influenced by revolutionary transformation (Hrubec 2014, 18). Transformation may then be explained as a manner, a process of performing revolutionary changes (Dvořáková 2014,7$)$.

H. Arendt framed her contemplations on revolution by the relationship, dominating in her view on the twentieth century, the question of war and revolution. Arendt's attempt "to think history" explains several problems. One of them is the standpoint according to which political theory has almost nothing to say as for the phenomenon of violence. Violence occurs beyond the political sphere and that was the reason why the seventeenth century scholars, in the time of wars and revolutions construed and made up the "natural condition". Of course, it was not and could not be a historical reality. Therefore, it cannot be understood from the point of view of development, i.e. the category important for the nineteenth century scholars, be it a cause and a consequence, a possibility and a reality, or a dialectic movement. According to Arendt, revolution cannot be grasped without the existence of the beginning. The German scholar recalls another idea related to justifications of wars which is as old as an organised combat. The experience with the Greek polis helped Arendt to see that political relationships do not imply violence. She insists that the "Greek polis, the city-state defined itself as the way of life that was based exclusively upon persuasion and not upon violence. That these were not empty words, spoken in self-deception, is shown, among other things, by the Athenian custom of those who had been condemned to death to commit suicide by drinking the hemlock cup, thus sparing the Athenian citizen under all circumstances the indignity of physical violation" (Arendt 2006, 12). However, beyond the walls of polis traditional rules applied "the strong does what he can and the weak one recoils". The modern notion of revolution is therefore accompanied by the idea that everything starts anew, a new story begins. The performers, having not a faintest idea what is going on at the beginning, will understand later, regardless of whether some of them sooner and some of them later, the 
meaning of this novelty. What was born as something new was freedom. Robespierre's term for his rule was despotism of freedom. And Condorcet knew that the term revolution could be used only if the goal of revolution was freedom. The birth of freedom is linked to the rise of the Greek polis in political history. This notion of no-rule was expressed by the word isonomy, whose outstanding characteristics among the forms of government, as the ancients had enumerated them, was that the notion of rule was entirely absent from it (Arendt 2006, 30). Isonomy was to provide equality, but not for all, as all people are naturally unequal, but as an institution the nomos of which made those who could be politically active politically equal, i.e. those who owned property and slaves. Thus, equality was an attribute of polis, not of people. Greek political thinking insisted on linkage of freedom and equality.

Modern thinking (Condorcet), when grasping and explaining freedom, insists that revolution strives for freedom, adding that a new story starts. The outcomes were not the rights to life, freedom and property ownership themselves but that they began to be deemed unalienable rights of man. However, the most important was the experience of the performers disclosing that something new was at its start. Besides, it was linked, as proved by the experience of French, American and finally also Russian revolutions, with an immense pathos, emphasising exceptionality, uniqueness of the event incomparable to anything by its grandeur and importance. For revolution, pathos is substantial. Not every coup d'etat, revolt, rebellion or a civil war can be deemed revolution. To understand revolution, violence itself is not sufficient, indeed. It is sensible to speak about revolution when there is a new beginning, the struggle against oppression, exchange of classes holding power, etc. When contemplating about the twentieth century, Tony Judt expressed his credo by the following words: Triumphant winners of the twentieth century were the liberals of the nineteenth century, whose successors built up social state in all its protean forms. They achieved something that looked almost inconceivable in the thirties: they created strong democratic and constitutional states with high taxing and active intervention policies that were able to absorb complex and mass societies without resorting to violence or repressions. It would be foolish to give up lightly this legacy (Judt 2012, 381). The issue the author wants to point out to has three levels: the performer, the theorist and the critic. However, at present, after eighty years of investments into public services a depression has come. We are repudiating the efforts, ideas and ambitions of the past. Through repudiation of wrong responses we ceased to ask right questions. Therefore, criticism coming after performance and theoretical attempts opens the space for criticism and seems to be inevitable.

We live in the world of unintended consequences of human activities. The German historian Gottfried Schramm studied revolutionary socialism. Majority of movements were marked by the existence of prescriptive texts as a typical and 
important sign. Why it was not so in Russia is a difficult question (Schramm 2004, 140-185). It is not then surprising that critical thinking of today is an accepted manner how to handle the consequences of highly improbable events. Russian revolutionaries wanted to restore and improve what was available at the time through reform methods. Inspired by the development in America they wanted to transform political democracy into social democracy. However, young radicals wanted more, something that has not existed here before. Part of restoration would be what was sensible to be preserved: human and civil rights with freedom of expression and protection of minorities as well as state with enforceable law. According to Schramm, Decabrists did not succeed to produce a prescriptive text similar to the American Constitution. We shall see what direction Russia and possibly Europe will take. History should not become a barrier in the search for alternatives. Michael Hauser in his review of the Marek Hrubec's magnum opus Od zneuznání $k$ spravedlnosti (From Disregard to Justice) perceives the situation also in the line restorer - innovator: we are in the situation calling for new theories or for reworking the old ones. Marek Hrubec's book should be read as a step in this direction, the step that is rare in the Czech environment. The book contains not only detailed interpretations, but a critical dialogue with respected authors in the first place. The author's basis is a contemporary critical theory in which he finds deficiencies and tries to overcome them. This occurs on the grounds of the triad: criticism, explanation, normativity, implying that critical theories have always been preferred in history one on the cost of the other, or of the third one (Hauser 2011, 564).

The emphasis on critical thinking is substantial; an expression of critical approach and search for prescriptive starting point are needed. The call for postmetaphysical approach is apparent here, critical thinking has no alternative.

What is common for contemporary discussions on "the situation today" is the arrival of equivocalness. Equivocalness or uncertainties enhance doubts; we ceased to feel secure in responding to our situation. The contemporary character of equivocalness is definitely directed by the movement of the financial capital as a new shape of the movement of organised modernity. Social sciences scholars, who resigned when studying the general, are confused. It is only the general crisis of the society we are experiencing today that returns us back to reality. Paradoxically, the new and newer forms of technology innovations only back up equivocalness and uncertainties; this, indeed, cannot be otherwise, as the general and equivocalness are fused. We have found ourselves in the world of revolution of side effects of modernity. In order for the equivocalness to disappear, it is necessary to remove those paradoxes that burden the understanding of substantial connections of side effects of modernity. Probably most paradoxical is the rise of incommensurability of social positions produced by special social worlds from the earlier inequalities. At social level, the differences in social positions became in- 
comparable and at political level a privileged elite emerged, distinct and separated from the rest of the society. However, the consequences of the asymmetry at political level are not discussed, as if it were governed by the principle of uncertainty, which is proved by the forced preventive manner of the functioning of politics. The performer cannot be separated from his activities. Politics seeks to predict what may happen but it does not know when. However, politics has always been an art of the possible. In the age of democracy, in human world, it does matter what theories, terms, categories and symbols stand for us. To stand for, to represent, means to make present something that is absent, even in the time when history is used as an argument against the search of alternatives. As the class extreme stated, the incommensurability of social positions, define the framework of social movement, it is very probable that the consequences of highly improbable events will be extreme.

Honneth perceives these processes going on in Western societies as both a structural social transformation and a very contradictory process at the same time. On the one hand, the processes characterised by terms like a reflexive modernisation or a knowledge society helped in the growth of individual freedom, but at the same time they were accompanied by socio-economic changes which have made the possibility to use these new options for a growing part of population difficult, or - in the process of economic efficiency principles realisation - they eliminated the newly acquired freedoms, or even occasionally they turned them to the contrary: every state needs cultural, political and legal recognition, which, however, are hard to be carried out on national and international level in the time of globalization. The theories of recognition so far offer suitable approach as for how to understand recognition beyond the borders of the nation-state; this, however, demands expressing of development options directed to trans-national recognition - new dilemmas arise within the passing on from uni-polar to multipolar world order. Real options of recognition enforcement beyond state borders show the inevitability to rely on the existing international institutionalisation of law and to attempt to over-cross it trans-nationally and globally, and redefine it consistent with the contemporary recognition attempts, resolved as inter-cultural as well as social and economic disputes (Hrubec 2011, 351).

\section{Democracy in the era of preventive politics}

Thus, the crisis of public authorities is a result of the situation of the current society. But the comment of Sartori still applies that the outcome of transformation is unpredictable. On the other hand, we can influence this outcome. Sartori personally did not expect that institutional changes all over the world will take such a pace and extent. Being scared when he discovered that when asking whether we 
know how to change, the response was a loud no and the ongoing reform events were marked by incompetence of the reformers. This may seem too harsh to say but it must be added immediately that many East European reforms were ill-considered. Globalization joined these phenomena and launched new processes of differrentiation, new ways of "taking away the chances" from "inappropriate" individuals or groups. Public authorities are looked at as mediators of corruption and users of useless violence - not as a protective shield for citizens, but as a citizen's burden (Sartori 1997, 11).

When studying the problem the distinction of the three levels can be of help, even though as a mere method: that is the distinction of performance, of theory and of criticism. The level of performance was outlined by Z. Bauman concentrating on liquid surveillance. If the entire acting is publicly available, then it will be the best protection against the poison of exclusion and the only way how to avoid the risk of deportation (Bauman 2011, 34).

On the contrary, critical theory must include such pieces of knowledge on the practice studied that are not part of performing or of (the existing theoretical) structures of meaning. The reason why the issue of revolution finds itself away from the framework of criticism is the "construct" of democracy as a preventive action. This is also the reason why the social issues are permanently marginalised. Perhaps, understanding of this problem was facilitated by Arendt's work on revolution. When comparing the two revolutions of the eighteenth century, the French and American, she concluded that while American revolution succeeded in terms of implementing the space of freedom as regards political institutions, the French revolution failed to achieve this. According to Arendt, the reason was social (Arendt 1965, 61-89). Thus "preventive democracy" appears to be a continuation of the first of the two revolutions.

Under preventive democracy we understand the state in which we accept the weigh and influence of the capital on the society; it is simply the name of the reality we live in today, as we react to the result of this fact. It is desirable to reflect that politics in the current condition and in its efforts to be politics presents itself as a prevention of the conditions, situations and further circumstances undesirable for the capital. In this sense it has become a form in which it removes the protective relationships created by the modern society. It expropriates the relationship it had created and therefore it is unable to face the consequences of its own policies. The picture arising here is rather a performance which is far from being over.

The question is to what extent the preventive nature of democratic methods will be capable of resolving the issue of complex protection. Not accidentally Thomas Hobbes focused, after Aristotle, on the key social factor, the phenomenon of self-preservation. Modernity is shown to be indeed a consequence of the development of protection relations (Keller 2007, 68-79). Modern state is an admi- 
nistrator of the forces of coherence in a society. Weakening of the state results in its being governed by "influential groups" which lack democratic control. The state must be considered a significant social innovation. But when considering that the problems the society is facing are rather remote from the ideal of a self-governing, associative civil society, we must admit the impacts of this fact. Preventive democracy is an attempt to give up this ideal. Modernity means stepping out from immaturity caused by one's own fault (Dahrendorf 2006, 41).

What the author names preventive democracy in this paper reminds one of protective democracy. Its goal was security in the first place, too. Symbol of protective democracy was the Bentham's panopticon. Symbol of preventive democracy was the Mathiesen's synopticon, often quoted by Bauman. But, can security be resolved through prevention? In the past, the development was directed to convergence of liberalism and democracy, eventually attempting to resolve social inequalities, as envisaged by Tocqueville.

The shape of globalization was never intended in advance to be as it finds itself today. The main performers, supra-national corporations arose only within its course and the principle of unintended consequences prevails in the entire system. Globalization leads to a rapid removal of national borders, relativisation of national cultures and makes knowing and converging of various cultures and ethnic groups more intense. The globalization consequences are widely discussed in Europe in particular. There are concerns that national and social state will become a victim of the rising phenomenon of globalization. It is nothing new. Extinction of nation-state during globalization is to be a result of the changed paradigm in economic policies of industrial countries. Their theoretical basis arises from monetarism, but the end result cannot be attributed solely to monetarism.

The phenomenon of insecurity entering our lives is closely connected with the decline of the bourgeois era, the era of state, money, industry, cities, privacy, family, education, book, representation, science and development of historical consciousness (Lukacs 2003, 21). Every feature can be subjected to a detailed study, but the author will agree with the opinion that with the exception of the last two, the others will decline and disappear. It is insecurity that makes theories subject to offer and demand. Immediate manifestation of this trend is in relation to the "here and now" form of democracy.

Such a form of democracy is far remote from an ideal, or, more precisely, it is more distant than desired by the elites themselves. Are these proofs that "democracy" entered the 21th century as a mere "political formula", just an empty terms intended to raise hope? Or, are new political formulae of the type of civil society, open society, society based on commonly shared values enforced? In the space of Central Europe the compounds like the path to Europe, integration of Europe can be indicated as political formulae: The admired and damned liberal democracy 
may become a mere political formula in Western Europe and partially in the USA (Goňcová 2013, 47).

Orientation is getting lost in the saturated solution of information. But it was the fact of incommensurability that has allowed for preventive actions to live. We need an explanation of the world enthused by culture of science, far away from the deadlocked social pessimism programmed by the incommensurability of today. The issues of democracy deformities in Slovakia are studied by Gbúrová (Gbúrová 2013, 47-61).

It is the repressive force of financial capital that has been allowing for "preventive democracy". Criticism will help both the performers and theorists to find the way out from this situation. Democracy is not an obligatory notion.

\section{References}

ARENDT, H. (1965): On Revolution. New York: Viking Press.

BAUMAN, Z. - LYIN, D. (2013): Liquid Surveillance: A Conversation. Wiley: Polity Press.

BRZEZINSKI, Z. (1998): The Grand Chessboard: American Primacy And Its Geostrategic Imperatives. New York: Basic Books.

DAHRENDORF, R. (2006): Versuchungen der Unfreiheit. Die intellektuellen in Zeiten der Prüfung. München: Beck.

DINUŠ, P. - HOHOŠ, L. - HRUBEC, M. (2014): Revoluce nebo transformace. Revolúcia alebo transformácia. Praha: Filosofia, Bratislava: VEDA.

FRASER, N. (1997): Justice Interruptus: Critical Reflections on the "Postsocialist" Condition. New York: Routledge.

GBÚROVÁ, M. (2012): K problematike deformít v súčasnej demokracii (slovenský príklad). In: Dobiáš, D. - Eštok, G. - Onufrák, A. - Brzdilová, R. (eds.): Zborník. Sloboda - rovnost' - poriadok. Košice: Univerzita Pavla Jozefa Šafárika, 7-27.

GOŇCOVÁ, M. (2013): Demokracie a společnost. In: Goňcová (ed.) et al: Demokracie? Brno: Masarykova univerzita, 44-67.

HABERMAS, J. (1991): The Structural Transformation of the Public Sphere: An Inquiry into a Category of Bourgeois Society (Studies in Contemporary German Social Thought). MIT Press.

HARVEY, D. (2011): The Enigma of Capital: and the Crises of Capitalism. London: Profile Books.

HAUSER, M. (2012): Marná hledání rovnosti výchozí situace. Recenze knihy: Marek Hrubec, Od zneuznání ke spravedlnosti. Kritická teorie společnosti a politiky. Praha: Filosofia. In: A2, č. 15/2012. Web. 21.09.2015. <http://www.advojka.cz/archiv/2012/15/teorie-uznani-a-velky-druhy> 
HOBSBAWM, E. (1994): The Age of Extremes: A History of the World, 19141991. London: Kings College.

HONETH, A. (2012): Integrita a zneuznání. Základní motivy morálky uznání. [Integrity and Disrespect: Principles of a Conception of Morality Based on the Theory of Recognition.] In: Hrubec, M. a kol.: Etika sociálních konfliktů. Praha: Filosofia, 215-231.

HRUBEC, M. (2011): Od zneuznání ku spravedlnosti. Kritická teorie globální společnosti a politiky. Praha: Filosofia.

JUDT, T. - SNYDER, T. (2012): Thinking the Twentieth Century. New York: The Penguin Press.

KAPLAN, R. D. (2013): The Coming Anarchy: Shattering the Dreams of the Post Cold War. Random House.

KELLER. J. (2007): Teorie modernizace. Praha: SLON.

LUKACS, J. (2003): At the End of an Age. Yale University.

ROBINSON, W. I. (2004): A Theory of Global Capitalism: Transnational Production, Transnational Capitalists, and the Transnational State. Baltimore: Johns Hopkins University Press.

SARTORI, G. (1997): Comparative Constitutional Engineering, An Inquiry into Structures, Incentives and Outcomes. London: Macmillan Press Ltd., Basingtoke.

SCHRAMM, G. (2004): Fünf Wegscheiden der Weltgeschichte. Ein Vergleich. Göttingen: Vandenhoeck \& Ruprecht.

SZOMOLÁNYI, S. (1999): Kl'ukatá cesta k demokracii. Bratislava: STIMUL.

VAROUFAKIS, Y. (2011): The Global Minotaur: America, Europe and the Future of the Global Economy (Economic Controversies). Zed Books.

prof. PhDr. Jozef Lysý, CSc.

Comenius University in Bratislava

Faculty of Education

Department of Ethics and Civics Education

Račianska 59

81334 Bratislava

Slovak Republic 